\title{
'Green' obligations regarding new constructions and their impact on the real-estate market
}

\author{
Simona CHIRICA \\ The Bucharest University of Economic Studies (ASE), Bucharest, Romania \\ Schoenherr si Asociatii (Bucharest)
}

PICBE | 560

\begin{abstract}
The fight for reducing green gas emissions and energy dependency requires the application of additional obligations for new constructions. From this perspective, starting from the $31^{\text {st }}$ of December 2020 building permits for new constructions in the private sector shall be issued only if their energy consume is close to zero. Additionally, the recovery level of non-dangerous waste resulting from construction and demolition activities must reach until the $31^{\text {st }}$ of December 2020 a percentage of minimum $70 \%$. Also, with respect to residential and non-residential buildings, new and also buildings undergoing major renovation, the real-estate developers must take into consideration the obligations regarding the instalment of electrical recharging points for electrical vehicles. These additional obligations will have a direct impact upon the construction price and will certainly influence the real-estate market.
\end{abstract}

Keywords: real estate, green obligations, real estate market, energy, green certificate.

\section{A. Buildings whose energy consumption is almost equal to zero}

At European Union level, buildings are responsible for about $40 \%$ of final energy consumption and $36 \%$ of greenhouse gas emissions ${ }^{1}$. From the energy consumption perspective at the national level, the residential and tertiary sector (office buildings, commercial spaces and other non-residential buildings) represent together $45 \%$ of the total energy consumption ${ }^{2}$. Considering that there is a tendency to expand this sector, it is obvious that both energy and raw material consumption will increase, which will also lead to an increase in the level of carbon dioxide emissions.

\section{Applicable legislative framework}

At the primary nation legislation level, one can observe the intention of the lawmaker to regulate, from the principal perspective, the energetical politic, namely the base objectives for the energetical efficiency.

Therefore, according to article 2 of the Law on electrical power and natural gases no. 123/2012 ('Energy law') ${ }^{3}$, the activities from the electrical energy field and the thermic energy produced in cogeneration must be performed in order to obtain the following base objectives: '(i) the promotion of use of new and renewable energy, (j) the insurance of the environment protection, locally and globally, in accordance with legal, in force provisions; (n) the promotion of electrical power, performed in highly efficient cogeneration systems, associated with thermal energy delivered for covering a justified economic consume.'

From the perspective of the legislation applicable at the European Union level, the field of energy efficiency is regulated mainly by Directive 2010/31/EU of the European Parliament and of the Council from 19th May 2010 on the energy performance of buildings ('Directive 2010/31/EU). The Directive 2010/31/EU repealed Directive 2009/91/EC and

\footnotetext{
${ }^{1}$ https://ec.europa.eu/energy/en/topics/energy-efficiency/buildings;

${ }^{2}$ https://ec.europa.eu/energy/sites/ener/files/documents/2014_article4_ro_romania.pdf;

${ }^{3}$ Published in the Official Gazette, Part I, no. 485, dated $16^{\text {th }}$ July 2012, as further amended.
} 
introduced substantial amendments to the energy performance requirements for buildings.

Law no. 372/2005 on the energy performance of buildings ${ }^{4}$ ('Law 372/2005') transposes fully into the national legislation the provisions of Directive 2010/31/EU, aiming to promote measures for increasing the energy performance of buildings by:

$>$ designing new buildings with low energy consumption;

$>$ thermal rehabilitation of existing buildings as well as

$>$ correctly informing the owners/administrators of the buildings on the energy performance certificate.

\section{New obligations on energy consumption}

In the context of new legal obligations regarding energy consumption, the following aspects should be taken into consideration: ${ }^{5}$

$>$ the new buildings from the private sector, for which the reception of the construction works is performed on the basis of building permit issued starting with the $31^{\text {st }}$ of December 2020, will be buildings that have the energy consumption almost equal to zero;

$>$ the new buildings owned/administrated by public administration authorities, which the reception of the construction works is performed on the basis of the building permit issued after $31^{\text {st }}$ December 2018, will be buildings that have energy consumption almost zero.

Therefore, according to the above mentioned, starting with 31 $1^{\text {st }}$ December 2020, building permits for new buildings from the private sector will no longer be issued unless they have nearly zero energy consumption. For buildings owned/administrated by public administration authorities, after $31^{\text {st }}$ December 2018, building permits for new buildings will not be issued unless they have nearly zero energy consumption. It may be noted that the legislator wished to impose for public authorities a stricter compliance deadline than the one for the private sector. These are corroborated with the national energetical politics, as per art. 4 paragraph (2) letter e) of Law 123/2012 'the increase of efficiency for the use of gas and energy'.

Romania undertook, with respect to the creation of capacities in order to reach the European global target $^{6}$, a national objective that until 2020, 24\% of the gross final consume of energy shall result from renewable energy sources and instated such objective in art. 5 paragraph (1) of law 220/2008 regarding the establishment of system for promoting of power production from renewable energy sources, as further amended 7 . Thus, one can easily observe the intention of the national and European lawmaker to obtain an efficient energetical efficiency, with respect to the production and also the consume.

The building for which energy consumption is almost equal to zero is defined by Law $372 / 2005$ as a building that meets the following cumulative conditions:

i. has a very high energy performance, with almost zero or very low energy consumption

\footnotetext{
${ }^{4}$ Law no. 372/2005 regarding the energetic performance of buildings, published in the Official Gazette, Part I, no. 1144 dated $19^{\text {th }}$ December 2005, as further amended;

${ }^{5}$ Article 14 of Law $372 / 2005$;

${ }^{6}$ At the consolidated level of the European Union, until 2020, the renewable energy sources msut represent $20 \%$ of the final gross consume of the European Union in 2020.

${ }^{7}$ As republished in the Official Gazette, Part I, no. 577 dated $13^{\text {th }}$ of August 2010.
} 
The notion of 'energy performance' of a building means the amount of energy calculated or measured to ensure the energy demand under the normal use of the building, which includes, inter alia, the energy used for heating, cooling, ventilation, hot water and lighting. ${ }^{8}$

ii. energy consumption is at least $10 \%$ covered by energy from renewable sources produced either on-site or nearby

Renewable energy is the energy from non-fossil renewable sources, namely: wind, solar, aerothermal, geothermal, hydrothermal, and ocean energy, hydropower, biomass, landfill gas, sewage treatment plant gas and biogas. ${ }^{9}$ Unfortunately, the legislator did not expressly define the proximity, leaving this assessment for the authorities and/or investors. However, we consider, de lege ferenda, that it is necessary to regulate this aspect in a future amendment to the law.

The level of energy required for buildings of which energy consumption is almost equal to zero is set by technical regulations. This level is differentiated on areas with renewable energy potential and is periodically updated/supplemented according to technical progress.

By city planning certificate [Romanian certificat de urbanism] issued in order to obtain the building permit, it will be necessary for the energy requirements of the buildings to be limited to the specific technical regulations ${ }^{10}$.

The city planning certificate issued without the observation of the provisions for the energy demand of buildings to be limited to the levels provided in the specific technical regulations, shall be considered as an incomplete city planning certificate $^{11}$. In this respect, the building permit issued under an incomplete city planning certificate is not valid and leads to the impossibility of obtaining of a building permit.

\section{The building's energy performance certificate}

The building's energy performance certificate (Romanian certificat de performanta energetica) is defined under Law 372/2005 as the documents established according to the calculation methodology of the energetic performance of buildings, that indicates the energetic performance of a building or of a building's unit and that comprises date regarding the primal and final consumption of energy, including the energy resulting from renewable energy sources as well as the quantity of $\mathrm{CO}_{2}$ emissions ('Performance certificate'), which is issued by persons that have the necessary certification issued by ANRE.

The existence of the Performance certificate is mandatory for (i) the establishment, (ii) the sale, (iii) the lease and for (iv) the performance of significant renovations of the following building categories: single family housing; apartment blocks; offices; education buildings; hospitals and restaurants; buildings designated for sport activities; buildings for trade services; other types of buildings that are energy consumer.

The Performance certificate contains:

$>$ calculated values, in accordance with the current technical regulations on energy consumption and $\mathrm{CO}_{2}$ emissions that allow the investor/owner/administrator of the building/building unit to compare and assess the energy performance of the building/building unit;

\footnotetext{
${ }^{8}$ Directive 2010/31/UE;

${ }^{9}$ Directive 2010/31/UE;

${ }^{10}$ Article 14 paragraph (4) of Law 372/2005;

${ }^{11}$ Article 32 paragraph (2) of Law 372/2005;
} 
recommendations to reduce the energy consumption of the building by estimating the energy savings through implementing measures to increase the energy performance of the building, including specifications from where to obtain more detailed information, such as: the cost-effectiveness of the recommendations made, the procedure that should be followed for the implementation of recommendations, financial or other incentives and funding opportunities.

For the buildings that are under the construction process, the certificate is established by the investor/owner/administrator, is presented in original to the reception commission at the end of the works, is attached, in copy, to the reception protocol and is part of the technical book of the construction.

\section{Consequences for non-observing the obligations on new energy performance obligations}

For new buildings in the private sector or owned/managed by the public administration authorities, who do not observe the above-mentioned obligations, namely do not have almost zero energy consumption, the reception of the construction works will not be performed, according to the provisions of the Regulation for reception of construction works ${ }^{12}$.

As a result of failing to perform the reception at the end of construction works or the lack of the reception's protocol, the construction cannot be put into use ${ }^{13}$.

Also, the ownership right of buildings may be registered in the Land Register on the basis of the protocol regarding the performance of the reception at the end of the construction works, accompanied by the documentation listed in Order no. 700/2014 regarding the approval of the Regulation for the approval, reception and registration in the cadastral records and land register, Official Gazette no. 571 of 31/07/2014, as further amended ('Order 700/2014').

Constructions made without a building permit or without the observance of its provisions, as well as those that do not have the reception at the end of the works performed, according the law, are not considered to be completed and cannot be registered in the land register ${ }^{14}$. Therefore, such constructions shall not be subject to transfer operations and shall not be transferred in the civil circuit.

According to the provisions of Order 700/2014, the unfinished constructions registered in the land register that do not have a reception protocol at the end of the construction works, cannot be subdivided into apartments.

\section{B. Instalment of electrical recharging points}

With respect to the new obligations regarding electrical recharging points, we indicate the provisions under Directive (EU) 2018/844 of the European Parliament and of the Council of 30 May 2018 amending Directive 2010/31/EU on the energy performance of buildings and Directive 2012/27/EU on energy efficiency ('Directive 2018/844').

Directive 2018/844 entered into force on 19.06.2018 and the term for the transposition in the national legislation is until 10.03.2020.

\footnotetext{
${ }^{12}$ Government Decision no. 343/2017 for the amendment of the Government Decision no. 273/1994 regarding the approval of the Regulation for the reception of construction works and related installations, in force since $29^{\text {th }}$ July 2017 , published in the Official Gazette, Part I no. 406 of May 30, 2017 ('Regulations for the reception of construction works');

${ }^{13}$ Article 5 of the Regulation on the reception of construction works;

${ }^{14}$ Law no. 50/1991 regarding the authorization of the execution of construction works republished Official Gazette no. 874 of November $1^{\text {st }}, 2016$, as further amended, comment Wolters Kluwer;
} 


\section{Applicability}

a) Non-residential buildings

With respect to non-residential building that are new and buildings that are undergoing major renovations that have more than 10 parking places ${ }^{15}$, it must be ensure that there are installed at least (i) 1 recharging place and (ii) the ducting infrastructure, namely conduits for electric cables, for at least 1 in every 5 parking spaces to enable the installation at a later stage of recharging points for electric vehicles where:

$>$ the car park is located inside the building, and, for major renovations, renovation measures include the car park or the electrical infrastructure of the building; or

$>$ the car park is physically adjacent to the building, and, for major renovations, renovation measures include the car park or the electrical infrastructure of the car park.

Also, the requests for the instalment of a minim of recharging points regarding non-residential building that have more than 20 parking places shall be determined by the member states until 01.01.2025. Therefore, they have time for studies and analyses for the elaboration and implementation of corresponding regulations, adapted according to each member state. This is the objective determined by the EU. The member state will have the mission to elaborate all the necessary details in order to implement this objective the most appropriate conditions.

b) Residential buildings

Regarding new residential buildings and residential buildings undergoing major renovation, with more than 10 parking spaces, it must be ensured that there is installed a ducting infrastructure, namely conduits for electric cables, for every parking space to enable the installation, at a later stage, of recharging points for electric vehicles, where:

$>$ the car park is located inside the building, and, for major renovations, renovation measures include the car park or the electric infrastructure of the building; or

$>$ the car park is physically adjacent to the building, and, for major renovations, renovation measures include the car park or the electrical infrastructure of the car park.

\section{Recycling of construction waste}

The construction sector is a significant generator of construction and demolition waste, representing approximately $25 \%-35 \%$ of the total waste generated by the European Union ${ }^{16}$. Reducing energy consumption and raw materials can be achieved by recycling waste resulting from construction and demolition activities.

The recycling of waste, including those resulting from constructions, is a process of waste valuation. This process saves both energy, because it reduces the number of industrial processes required for production, as well as raw material for the production of the finished product. Reuse of construction and demolition waste reduces waste disposal space and allows the use of recycled materials instead of natural resources.

\section{Applicable legislative framework}

\footnotetext{
15 To be observed that for each type of construction, namely for the counties and the Bucharest Municipality there are strict re gulations regarding the minimum parking places that must be built by a real-estate developer in order obtaining the building permit.

16 http://ec.europa.eu/environment/waste/construction_demolition.htm;
} 
Directive 2008/98/EC of the European Parliament and of the Council from $19^{\text {th }}$ November 2008 on waste and repealing certain Directives ('Directive 2008/98/EC') sets objectives that need to be achieved by the Member States of the European Union in the field of waste recycling, by 2020 .

At national level, Law no. 211/2011 on the waste treatment ${ }^{17}$ ('Law 211/2011') transposes Directive 2008/98/EC and seeks to establish measures for the environment protection and public health, by preventing or reducing the adverse effects of waste generation and waste management. Law 211/2011 also aims to reduce the overall effects of resource use and increase the efficiency of its use.

\section{The principle 'polluter pays'}

Waste represents any substance or object that the holder discards or intends to discard. ${ }^{18}$ The 'polluter pays' principle is a guiding principle at European and international level. According to the 'polluter pays' principle, the cost of waste management is to be borne by the original waste producer or by the current owners or previous holders of that waste ${ }^{19}$.

The notion of waste producer means any person whose activities generate waste. From this perspective, waste producers are considered both the original waste producer as well as any other person who performs pre-treatment, mixing or other operations that change the nature or composition of such waste.

Regarding the waste holders, this category includes either waste producers, or physical or legal persons who have waste in their possession.

\section{Minimum quantity of construction waste that needs to be recycled}

Holders of construction and/or demolition permits are required to manage construction and demolition waste. Managing this type of waste involves reaching, by $31^{\text {st }}$ December 2020, a level of preparedness for re-use, recycling and other material recovery operations, including filling operations, landfills that use waste to replace other materials, of at least $70 \%$ of the mass quantities of non-hazardous waste resulting from construction and demolition activities. ${ }^{20}$

In the Annex of the Commission's Decision of 18th December $2014^{21}$ ('Commission Decision 2014'), point 17 lists the categories of construction and demolition wastes that are classified as hazardous and those classified as non-hazardous. Based on these lists, the selection of non-hazardous waste for recycling will be made in order to progressively reach recycling levels of at least $70 \%$ of the non-hazardous waste mass by $31^{\text {st }}$ December 2020.

According to Annex no. 6 of Law 211/2011, annual obligations on the level of preparedness for re-use, recycling and other material recovery operations, including filing operations, landfills that use waste to replace other materials of legal entities on whose behalf the permits of construction/demolition are issued, must be:

a) at least $30 \%$ of the amount of construction activity waste from 2017;

b) at least $45 \%$ of the amount of construction activity waste from 2018 ;

c) at least $55 \%$ of the amount of construction waste from 2019 ;

d) at least 70\% of the amount of construction activity waste from 2020.

\footnotetext{
${ }^{17}$ Law no. 211/2011 on the waste treatment, published in the Official Gazette no. 837 from $25^{\text {th }}$ November, 2011;

${ }^{18}$ Point 9 from Annex no. 1 of Law 211/2011;

${ }^{19}$ Article 14 (1) of Directive 2008/98/EC;

${ }^{20}$ Article 17 paragraph (3) of Law 211/2011;

${ }^{21}$ The Commission's Decision dated 18 December 2014 for the amendment of Decision 2000/532/CE for the establishment of a

waste list under the Directive 2008/98/CE of the European Parliament and Council;
} 
The above mentioned annual obligations are calculated on the basis of the quantities of waste generated in that year.

D. The impact of 'green' obligations on the real estate market

The implementation of technical solutions on (i) the performance of buildings for which energy consumption is almost zero, (ii) the installation of electrical recharging stations and (iii) the achievement of the required recycling rate of construction and demolition PICBE | 566 waste, will most likely involve additional costs for investors and real estate developers. These additional costs will most probably be reflected in the final selling price of the buildings, namely the cost of rent (both in the residential and non-residential sectors).

Although long-term needed, these environment protection measures will be a challenge regarding their implementation.

\section{Bibliography}

Directive 2008/98/EC of the European Parliament and of the Council from 19th November 2008 on waste and repealing certain Directives;

Directive 2010/31/EU of the European Parliament and of the Council from 19th May 2010 on the energy performance of buildings;

Government Decision no. 343/2017 for the amendment of the Government Decision no. $273 / 1994$ regarding the approval of the Regulation for the reception of construction works and related installations, in force since 29th July 2017, published in the Official Gazette, Part I no. 406 of May 30, 2017;

Law no. 211/2011 on the waste treatment, published in the Official Gazette no. 837 from 25th November 2011;

Law no. 372/2005 regarding the energetic performance of buildings, published in the Official Gazette, Part I, no. 1144 dated 19.12.2005, as further amended;

Law no. 50/1991 regarding the authorization of the execution of construction works republished Official Gazette no. 874 of November 1st, 2016, as further amended;

Order no. 700/2014 regarding the approval of the Regulation for the approval, reception and registration in the cadastral records and land register, Official Gazette no. 571 of 31/07/2014, as further amended;

The Commission's Decision dated 18 December 2014 for the amendment of Decision 2000/532/CE for the establishment of a waste list under the Directive 2008/98/CE of the European Parliament and Council;

http://anre.ro

http://ec.europa.eu/environment/waste/construction_demolition.htm.

https://ec.europa.eu/energy/en/topics/energy-efficiency/buildings;

https://ec.europa.eu/energy/sites/ener/files/documents/2014_article4_ro_romania.pd $\mathrm{f}$; 